\title{
Shcherbina $0 . \quad$ DEVELOPMENT OF IMITATION MODEL FOR SELECTION OF TUG BARGE VESSELS FOR WORK ON THE LINE
}

\begin{abstract}
Досліджено маршрутну форму організачії роботи баржебуксирних суден з наскрізною формою роботи тяги і змінною формою узгодження роботи тяги і тоннажу в кінщевих пунктах. Визначено необхідність врахування відповідності лінійних і технічних характеристик суден умовам майбутнього рейсу. Розроблена методика дозволяє за допомогою імітаційної моделі виконати попередній відбір суден для роботи на лінії.
\end{abstract}

Ключові слова: імітаційна модель відбору баржебуксирних суден, марирутна відправка, форма організаиї роботи.

\section{Introduction}

In conditions of stable cargo traffic, one of the most effective forms of organizing tug barge vessels (TBV) is the work on the principle of routing dispatch with endto-end information and technical tasks.

Routing dispatch means transportation in which the number of ships does not change throughout the voyage. Thus, the compound at the barge loading points or close to these points, follow up to the disbanding points located at the barge unloading points or near these points. Also, the number and composition of non-self-propelled vessels entering into the TBV does not change on all routes, and cargo operations (loading or shipping) are not performed with them. Thus the form of work of draft can be both through, and divisional.

When organizing route transportations, it is necessary to take into account the throughput capacity of the loading and unloading points in order to avoid the idle time in them. For this purpose, the formed route composition should consist of as many barges as the destination can simultaneously accept.

The application of this method of organizing the work of ships allows to reduce or eliminate unnecessary re-mooring, loading, re-composition and operations with cargo. As a result, there is an increase in such indicators as productivity and carrying capacity of ships, acceleration of cargo delivery and, accordingly, reduction of the required fleet [1].

At through haulage there is provided work with routing compositions, which is the work of traction from the point of departure (formation) of the composition to the point of its destination (disbandment). The uninterrupted form of tug's work, corresponding to the work of vessels on the «dedicated traction shoulder», is recommended for powerful steady ship streams throughout navigation. In addition, the through form is recommended in all directions, which have relatively equal conditions of navigation. As a rule, these are the middle and bottom sections of the magistral rivers [2].

In the practice of operating the TBV with this method of coordinating the movement of traction and tonnage as the fixing of the tug for the compound on individual flights, there are ways to fix the tug for the composition for the flight (exchangeable) and for circular flights (mixed) [1].

Exchangeable form of operation of the work of the TBV means readiness of the barges in the ports by the time of vessel's arrival and the tug's release from the previous voyage. At the same time, there are practically no outages of tugboats in waiting of barges, and insignificant traction downtime of are not excluded. Without waiting for the processing of the tonnage at both points, the tug takes the prepared compound at the point and leaves for a new flight.

The effectiveness of the mixed method of fastening is ensured by high rates of cargo handling in one of the ports. This fact predetermines the exclusion of downtime of tonnage in anticipation of tug and the elimination or minimization of downtimes of tug in anticipation of tonnage. Since the application of this method of fixing in river transport is not expedient due to the low norms of cargo handling, therefore, in the present work it is not considered.

Since the norms of cargo operations in river ports are not sufficient for applying the mixed method of fixation, therefore, in this paper it is not considered.

In practice, the operation of river transport with a exchangeable form of joint work of tug and tonnage and the through form of tug's work is called a «drop-andswop» [3]. This means that tug at the final points, without waiting for the handling of the delivered tonnage, takes the prepared compound in the port and is sent to a new flight from the point of departure to the destination of the cargo.

The increased interest in the transportation by TBV, well-founded in [3-6] at this time, makes the actual topic of the study.

\section{The object of research and its technological audit}

One of the issues of the organization of the work of the vessels is their selection from the priority series in order to ensure the greatest correspondence of the linear and technical characteristics of vessels to the conditions of the coming voyage. Thus, the subject of the study is 
the methods of selecting the sizes of the TBV for work on the scheme in submitted form of organization. As an object of research is the process of the work of the TBV in a definite organizational form.

As is known, the efficiency of the operation of the TBV depends of the rational combination of tug and tonnage (the type size of the vessel). The type size of the TBV is determined by the type and power of the tug; type, number of barges (tonnage); form of connection barges; the method of driving compound from barges. In studying the work of the TBV comes to the conclusion, that their size is influenced mainly by the following physic-geographical factors:

- area of navigation;

- parameters of the ship's run (straightness, curvature, width, depth, tortuosity, availability of locks);

- flow parameters (speed and direction);

- wind-wave mode;

- water level parameters;

- other characteristics of inland waterways (the slope of the river, the ground of the bottom and its condition, the presence of vegetation, the duration of navigation).

The above factors have a direct effect on ship parameters such as the linear characteristics of the TBV (length, width and draft), the number of barges in the construct, the total carrying capacity of the vessel:

a) the guaranteed depth limits the draft of the vessel;

b) the radius of curvature, the length of the lock chamber limit the length of the vessel;

c) the width of the fairway and the lock chamber limits the width of the construct;

d) the height of the span under the bridges limits the height of the vessel above the water with the spar.

Accounting for the identified dependencies will simplify the process of forming a priority series of TBV and, therefore, reduce the total time for the organization of the transport process.

\section{The aim and objectives of research}

The aim of research is development of a methodology for the formation of a priority series of tug barge vessels for work on the line with a certain method of their operation based on the limitations on the route on carrying capacity and linear characteristics.

To achieve this aim needs:

1. Determine the relationship between the TBV parameter and the factor affecting the vessel's size.

2. Develop a imitation model for the selection of vessels.

\section{Research of existing solutions of the problem}

Most of the domestic research in the field of tug barge transport belongs to the period of 70-80-years of XX century. The need for new research is mainly related to the expansion of the scope of operation of the TBV in the investigation:

- introduction of containerization in river transportations;

- application of modern engineering developments for coupling devices;

- changes in the technology of the coordinated work of sea and tug barge vessels.
All of the above innovations led to changes in the theory of the organization of the work of the TBV.

The literature on the subject of the study has shown that the issue of selecting vessels for work on the line has not been given due attention either in the works of the Soviet period or in contemporary studies of the last decade.

In a series of papers [3, 4], a model was proposed for determining the optimal characteristics of a mixed river-sea swimming from the position of shipbuilding and engineering. The author suggests selecting the vessels whose characteristics provide economic efficiency. This solves a particular problem for a certain direction and group of vessels for the variant with a raid transshipment complex [3]. In the proposed technique [3, 4], it is not indicated how the main linear dimensions of the vessels are taken into account for various forms of the organization of the TBV operation.

In scientific research, presented in the foreign literature, barge transportations are mainly considered in the following directions:

- highlights the development strategy of transportations by a tug barge vessels (TBT) [5, 6];

- in the field of intermodal container transport [7-10];

- in the field of shipbuilding;

- in the field of navigation.

If the last two areas of research in the domestic and foreign literature coincide, then in the field of commercial exploitation, there are fundamental differences. In this regard, the issues considered in domestic and foreign studies are differed.

Thus, in $[7,8]$, a method for determining and estimating is proposed:

- variants of intermodal container delivery schemes

for European inland waterways;

- places of dislocation of hub ports.

The presented technique is of interest in determining the port change of tug with the local form of organization of the work of TBV for the transport of bulk goods.

In [8], the authors propose a network design model, noting that tasks related to the planning of transport operations are specializations and variations of the general model of building a transportation network. Presented in the work model for the implementation of barge service in intermodal transport allows to design a scheme of delivery of goods without binding to ships. The initial information for the solution of the model is information about the container flows and the necessary time of a circular voyage.

The models presented in $[9,10]$ have been developed for river-sea navigation vessels as a whole. At the same time, they adapt easily enough to TBT for certain organizational forms of work of vessels. The presented model is applicable for the operation of the TBV by the principle of a combined shipment with a through form of tug work and exchangeable form of coordination of the work of tug and tonnage at the points of departure and destination. When implementing this methodology, the schemes of work of vessels are determined.

However, unlike the previous models [7, 8], the model [9] is more stringent, as it is limited by the characteristics of ships and cargo flows. From the methodology presented in [10], it can be clearly seen that the choice of the vessel's limiting performance (speed and payload), 
and, consequently, of the vessel itself, for a certain scheme is carried out according to the economic performance of the vessels.

The paper [11] presents the main terminology used in the TBT and the requirements for determining the main linear dimensions of TBV, when operating in the Great Lakes. The difference in the requirements for determining the permissible sizes of TBVs presented in [4, 11] is due not only to different conditions of navigation, but also to the level of necessary accuracy of the results obtained.

Thus, the conducted analysis of the publications confirmed the novelty of the carried out research presented in the present work.

\section{Methods of research}

The task of ships disposition along the lines is quite complicated. To simplify the calculations at the first stage of solving the task of organizing the operation of the TBV, it is expedient to select vessels that can operate on the line with a certain variant of the organization. In selection takes into account the characteristics of the route, which imposing limitation on the vessel's carrying capacity and its linear dimensions. For this purpose, it is expedient to apply imitation modeling, in which results is composition and consistency of operations to determine the possibility of the TBV operation on the scheme under a certain variant of their operation.

To implement the task, the following requirements and conditions for the flight must be taken into account:

- the cargo can be delivered from one river port into the raid of river (or sea) port by the TBV of river (or mixed river-sea) navigation, both in the forward and reverse directions;

- the cargo can be delivered by the TBV of sea or mixed navigation both from the seaport to the raid (wellhead) port, and in the opposite direction;

- on the track there may be lock point (points of flight conditions change);

- various combinations of TBV from barges (sections) of different carrying capacity and tugs (tractors) of different power are possible.

A variant of the imitation model for selecting the TBV for work on the line with an appropriate representation of the composition of the ship selection operations is proposed, proceeding from the fact that the investigated variant of the operation of the TBV is based on:

- route transport, in which the components of the TBV and their number does not change throughout the voyage;

- a through form of organizing the work of tug, in which the same TBV carries out transportation from the initial port to the final port (which is a river or sea port, port raid);

- an exchangeable form of operation of the TBV.

The imitation model is based on the need to analyze the possibility of work of the TBV on the region, to taking into account the influence of the route restrictions on the technical and operational characteristics of the vessel (the length and width TBV, its loading capacity and draft with cargo). To do this it is necessary:

- to determine on the scheme of motion the regions $\delta$, on which the value of the characteristics of the ship's way differ sharply;
- to designate their boundaries;

- to determine the maximum allowable loading capacity of the TBV and (or) the number of barges for the section $\delta$ of the scheme $\ell$ according to the limitations at the route.

The model provides for the preliminary selection of the TBV of the type $z$ from a number of vessels offered for work on the line by checking the compliance of their characteristics with the maximum permissible parameters. The method of forming the size of the TBV for work on the line, the result of which is a number of vessels offered for work on the line, is presented in [12].

The following symbols are used in the model:

$\delta=\overline{1, \Theta}$ - parameter that determines the section of the scheme;

$z=\overline{1, Z}$ - parameter that determines the type size of TBV;

$\ell=\overline{1, L}-$ parameter that defines the scheme;

$r=\overline{1, R}$ - parameter that determines the cargo flow;

$i=\overline{1, I I}$ - parameter that determines the type of thrust;

$L_{z \ell}$ - total length of the TBV of the type $z$ when working by the scheme $\ell, \mathrm{m}$;

$B_{z \ell}$ - the total width of the TBV of the type $z$ when working by the scheme $\ell, \mathrm{m}$;

$T e_{z \ell}$ - operational draft of the TBV type $z$ limited by the route conditions of the scheme $\ell, \mathrm{m}$;

$D c \max _{\delta}$ - the maximum permissible load capacity of the TBV when operating in the section $\delta$ based on the limitations, $\mathrm{t}$;

$L \max _{\delta}$ - the maximum permissible length of the TBV in the section $\delta$ based on the constraints, $\mathrm{m}$;

$B \max _{\delta}$ - the maximum permissible width of the TBV in the section $\delta$ based on the constraints, $\mathrm{m}$;

$T \max _{\delta}$ - the maximum permissible draft of the TBV in the section $\delta$ based on the limitations, $m$;

$D c \max _{\ell}$ - the maximum permissible load capacity of the TBV when operating by the scheme $\ell$, based on the limitations, $\mathrm{t}$ :

$$
D c \max _{\ell}=\max \left\{D c \max _{\delta}\right\}, \delta=\overline{1, \Theta} ; \ell=\overline{1, L},
$$

where $L \max _{\ell}$ - the maximum permissible length of the TBV on the scheme $\ell$ based on the constraints, m:

$$
L \max _{\ell}=\max \left\{L \max _{\delta}\right\}, \delta=\overline{1, \Theta} ; \ell=\overline{1, L},
$$

where $B \max _{\ell}$ - the maximum permissible width of the TBV on the scheme $\ell$ based on the constraints, m:

$$
B \max _{\ell}=\max \left\{B \max _{\delta}\right\}, \delta=\overline{1, \Theta} ; \ell=\overline{1, L},
$$

where $T \max _{\ell}$ - the maximum permissible draft of the TBV on the scheme $\ell$ based on the constraints, $m$ :

$$
T \max _{\ell}=\max \left\{T \max _{\delta}\right\}, \delta=\overline{1, \Theta} ; \ell=\overline{1, L},
$$

where $Q_{z r \ell}$ - the maximum permissible load of a barge or vessel set based on limitations (the method for determining it is set forth in [12]).

Since the routing dispatch is loaded at the departure port and sent to the port of destination, it is advisable to consider the possibility of the TBV on the scheme when the following limitations are fulfilled in general for the scheme $\ell$ : 


$$
\begin{aligned}
& Q_{z r \ell} \leq D c_{p}^{z \ell}-\Delta D c, z=\overline{1, Z} ; r=\overline{1, R} ; \ell=\overline{1, L}, \\
& D c_{p}^{z l} \leq D c \max _{\ell}, z=\overline{1, Z} ; l=\overline{1, L}, \\
& T e_{z \ell} \leq T \max _{\ell}, z=\overline{1, Z} ; \ell=\overline{1, L}, \\
& L_{z \ell} \leq L \max _{\ell}, z=\overline{1, Z} ; \ell=\overline{1, L}, \\
& B_{z \ell} \leq B \max _{\ell}, z=\overline{1, Z} ; \ell=\overline{1, L},
\end{aligned}
$$

where $D c_{p}^{z \ell}-$ the register load capacity of the TBV type $z$ when operating on the scheme $\ell$; $\Delta D c$ - the limit of the tolerance in the load, specified in advance.

The method for determining the register loading capacity of a TBV of the type $z$ on operating by the scheme $\ell\left(D c_{p}^{z \ell}\right)$ is described in [12], which reduces to the following:

$$
D c_{p}^{z \ell} \leq D c_{\max }^{z \ell}, z=\overline{1, Z} ; \ell=\overline{1, L},
$$

where $D c_{\max }^{z \ell}-$ the maximum permissible load capacity of the TBV type $z$ when operating by the scheme $\ell$ :

$$
\begin{aligned}
& D c_{\max }^{z \ell}=\min \left\{D c_{p}^{z} \max _{i} ; D c \max _{\ell}\right\}, \\
& i=\overline{1, I} ; \quad z=\overline{1, Z} ; \ell=\overline{1, L},
\end{aligned}
$$

where $D c_{p}^{z} \max _{i}$ - the maximum register load capacity of the type $z$ TBV when working with a tug type $i$ :

$$
D c_{p}^{z} \max _{i}=\rho_{i} \cdot N_{i}^{e}, i=\overline{1, I} ; z=\overline{1, Z},
$$

where $\rho_{i}-$ the specific load of thrust of type $i, \mathrm{t} / \mathrm{kW} ; N_{i}^{e}-$ power of the power plant of thrust of type $i, \mathrm{~kW}$.

\section{Research results}

The composition and sequence of operations in the imitation model are shown in Fig. 1.

The appoint No. 1 in block 6 means that the limitations (5)-(9) are considered, and the TBV is fully loaded at the starting point $(d=1)$ of the scheme 1 according to the maximum permissible loading capacity.

Cells marked with «0» in block 7 indicate the inadvisability of using a type $z$ TBV on the scheme, since the TBV load capacity $\left(D c_{p}^{z \ell}\right)$ or its linear characteristics $\left(T e_{z \ell}, L_{z \ell}, B_{z \ell}\right)$ do not meet the requirements of the scheme for vessels.

In block 8, a matrix of the results of the preliminary selection of vessels for working on the scheme is formed.

Iterations are performed until all the TBVs of type $z$ are checked.

In block 10, the results are processed, as a result of which of which it is determined possibility of TBV operation of the type $z$ on the scheme 1 with the route dispatch.

In block 11, the basis of the vessels $S^{\alpha}=\left\{z^{\alpha d \tau}\right\}$ is formed, which should be considered as a possible TBV of the type $z$ for work on the scheme between the ports $d \leftrightarrow \tau$ in the case of the vessels operation on the route dispatch $\alpha$.

Block 12 compiles a priority series from the TBV of type $z$ for work according to the scheme.

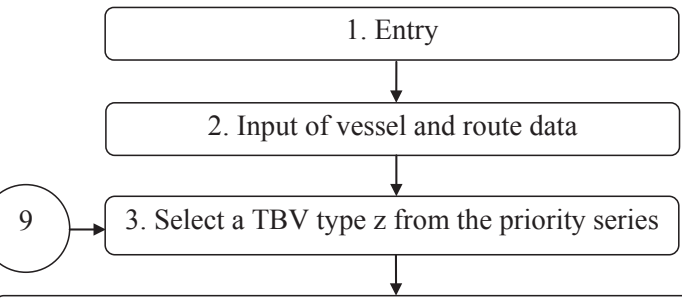

4. The verification the execution of the limitations for the scheme $\ell$
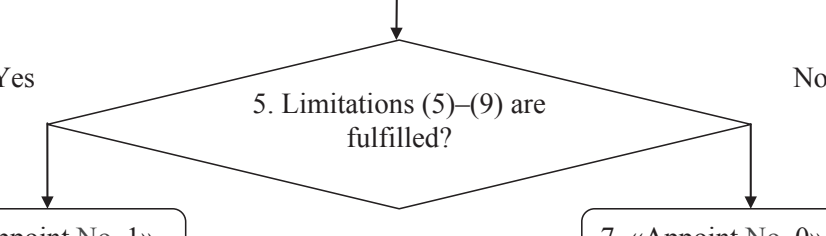

No
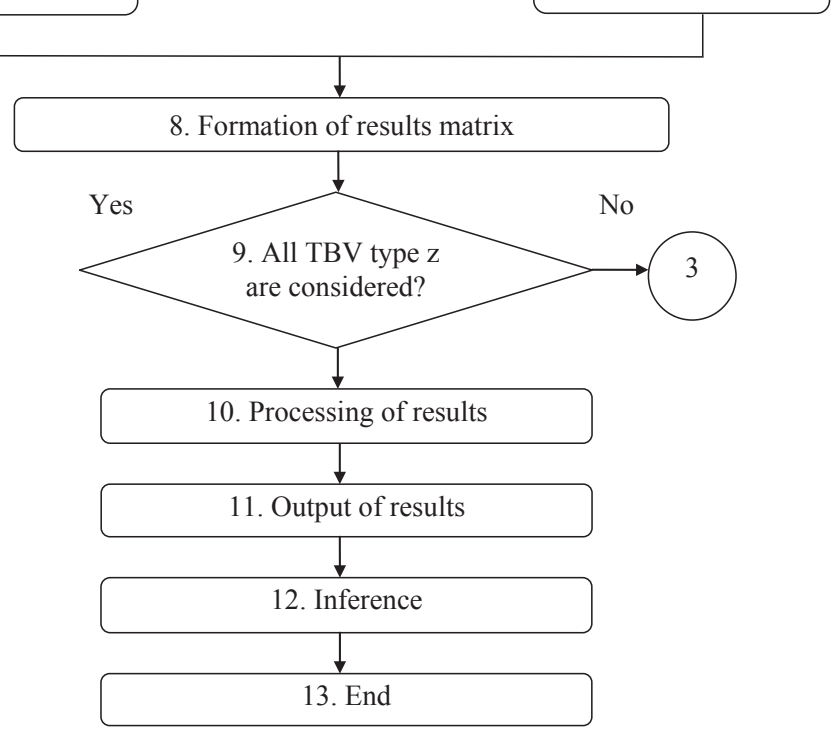
vessels for work on the line for route dispatch

In this case, the first sequence number is assigned to the TBV of type $z$, for which the value maximum permissible load of barge $\left(Q_{z r \ell}\right)$ is the largest, and then, in descending order the values of this mark.

As a result of data processing according to the above procedure, at the output from block 8 we obtain information for analysis in the form of a table, an example of which is presented in Table 1.

Table 1

Matrix of the results of the preliminary selection of vessels for work by the scheme

\begin{tabular}{|c|c|}
\hline \multirow{2}{*}{ TBV type $z$} & Regions $\delta$ \\
\cline { 2 - 2 } & 1 \\
\hline 1 & 1 \\
\hline 2 & 1 \\
\hline$\ldots$ & 0 \\
\hline$z$ & 0 \\
\hline
\end{tabular}

Cells marked with «0» indicate the inadvisability of using the TBV type $z$ on the scheme, since its load capacity is not fully used $\left(D_{c p}^{z \ell}\right)$ or its linear characteristics $\left(T e_{z \ell}, L_{z \ell}, B_{z \ell}\right)$ do not satisfy the requirements of the scheme of work for vessels. Thus, in the example given (Table 1), 
the TBV No. 1 and No. 2 fully comply with the requirements of the scheme and can be considered in subsequent developments when working on a scheme in a route dispatch.

In the future, an evaluation should be made of the feasibility of operating the TBV of the type $z$ and its further fixing according to the voyage scheme $\ell$.

\section{SWOT analysis of research results}

Strengths. The strength of the study is a detailed study of the proposed form of organization of the TBV operation, which resulted in the following conclusion:

- work should be carried out between two points on a regions with relatively equal conditions of navigation without re-composition and loading (unloading);

- the form of the work of TBV is effective in the presence of powerful, stable cargo flows.

The introduction of research results at enterprises does not require additional capital investment. At the same time, the necessary training of personnel is carried out within the framework of advanced training of production personnel.

Weaknesees. The weak side of the conducted research is the absence in the study of the full course of calculations for the formation of a priority series of TBV based on the selection of ships for work on the scheme to meet the constraints imposed on the conditions of the forthcoming voyage.

Opportunities. Further development of the approach assumes an assessment of the advisability of operating a TBV type $z$ from the priority series on the line with its subsequent fixing. The proposed methodology is designed to:

- reduce the time for processing information when

making a decision to organize the work of the TBV;

- increase the profit of the shipping company by in-

creasing the carrying capacity of the vessel with the

best adjustment of the transport characteristics of the TBV and the route.

Threats. The tasks considered in the work are included in the complex of problems of optimal planning of the work of the tug barge fleet. In this regard, there is a threat of mismatch between the results of this and subsequent research.

\section{Conclusions}

1. In analyzing the proposed form of organization of work the TBV concluded that the type size of the vessel, and therefore, the work of the ships is influenced mainly by physical and geographical factors. The theoretical aspect of the influence of these factors goes beyond the scope of this paper and is an independent study. The relationship between the TBV parameter and the physic-geographical factor is shown in the limitations (5)-(9). Since these factors limit the maximum length of the vessel, its width, draft and load capacity, then compliance with the constraints allows us to determine the type size of the TBV consisting of a certain type of tugboat, barges and their number and characteristics of the barges connection (connecting barge with each other).

2. The imitation model proposed in the study makes it possible to perform a preliminary selection of vessels for work on traffic scheme, which simplifies the calculations associated with the allocation, of vessels. The model is based on the need to take into account the physical and geographical factors in the organization of the work of the TBV on inland waterways in order to ensure the greatest correspondence of the linear and technical characteristics of the ships to the conditions of the forthcoming voyage. The developed group of limitation takes into account the peculiarities of the considered form of the TBV organization and is rational only for it, since it takes into account that the TBV loaded in the port of departure should go to the destination without reorganization and loading (unloading).

\section{References}

1. Shcherbina O. V., Shybaiev O. H. Osnovni pryntsypy orhanizatsi roboty barzhe buksyrnykh suden // Orhanizatsiia transportnoho protsesu ta upravlinnia robotoiu flotu na rynku mizhnarodnoho sudnoplavstva: Collective Monograph. Odesa: KUPRIIeNKO SV, 2017. Part 2. P. 69-79.

2. Liahov K. S., Heifets M. B. Grafik dvizheniia flota (osnovy teorii i raschet). Moscow: Rechnoi transport, 1962. 186 p.

3. Egorov A. G. Modeli ekspluatatsii sostavov smeshannogo rekamore plavaniia // Morskoi vestnik. 2015. No. 1. P. 101-107.

4. Egorov A. G. Matematicheskaia model' opredeleniia glavnyh harakteristik sostavnyh sudov // Morskoi vestnik. 2015. No. 2 P. $85-89$.

5. Wiegmans B. W., Konings R. Strategies and innovations to improve the performance of barge transport // European Journal of Transport and Infrastructure Research. 2007. Vol. 7 , No. 2. P. $145-162$.

6. Malchow U. Port Feeder Barge: Advanced Waterborne Container Logistics for Ports // TransNav, the International Journal on Marine Navigation and Safety of Sea Transportation. 2014 Vol. 8, No. 3. P. 411-416. doi:10.12716/1001.08.03.12

7. Konings J. W. Intermodal Barge Transport: Network Design, Nodes and Competitiveness: Doctoral Thesis. TRAIL Research school 2009. URL: http://repository.tudelft.nl/view/ir/uuid\%3Aff6f5f102acc-43fb-9474-5317b0988bdd/ (Last accessed: 17.12.2017).

8. Caris A., Macharis C., Janssens G. K. Modelling corridor networks in intermodal barge transport. 12th WCTR, July 11-15, 2010. Lisbon, Portugal, 2010. 25 p. URL: http://www.wctrssociety.com/wp/wp-content/uploads/abstracts/lisbon/selected/ 01919.pdf (Last accessed: 17.12.2017).

9. Kaup M. Functional model of river-sea ships operating in European system of transport corridors: Part I. Methods used to elaborate functional models of river-sea ships operating in European system of transport corridors // Polish Maritime Research. 2008. Vol. 15, No. 3. P. 3-11. doi:10.2478/v10012-007-0077-y

10. Kaup M. Functional model of river-sea ships operating in European system of transport corridors: Part II. Methods of determination of design assumptions for river-sea ships operating in European system of transport corridors, according to their functional model // Polish Maritime Research. 2008. Vol. 15, No. 4. P. 3-11. doi:10.2478/v10012-007-0090-1

11. Guide for Building and Classing - Integrated Tug-Barge (ITB) Combinations Intended to Operate on the Great Lakes American Bureau of Shipping. November 2002. No. 110. URL: https://preview.eagle.org/eagleExternalPortalWEB/ShowProperty/BEA\%20Repository/Rules\&Guides/Current/110 IntegrTugBargeCombIntendedtoOperateGreatLakes/Pub110 ITB GreatLakes (Last accessed: 17.12.2017).

12. Shcherbina O. Determination of size the tug barge composition // Visnik of the Volodymyr Dahl East Ukrainian National University. 2017. No. 4 (234). P. 248-253.

\section{РАЗРАБОТКА ИМИТАЦИОННОЙ МОДЕЛИ ОТБОРА} БАРЖЕБУКСИРНЫХ СУДОВ ДЛЯ РАБОТЫ НА ЛИНИИ

Исследована маршрутная форма организации работы баржебуксирных судов со сквозной формой работы тяги и сменной формой согласования работы тяги и тоннажа в конечных пунктах. Определена необходимость учета соответствия линейных и технических характеристик судов условиям предстоящего рейса. Разработанная методика позволяет при помощи имитационной модели выполнить предварительный отбор судов для работы на линии.

ключевые слова: имитационная модель отбора баржебуксирных судов, маршрутная отправка, форма организации работы.

Shcherbina Olga, Assistant, Department of Fleet Operation and Technology of Sea Transportation, Odessa National Maritime University, Ukraine, e-mail: olahome@rambler.ru, ORCID: https://orcid.org/ 0000-0001-5029-6098 